ASTHMA

\title{
Inflammation of bronchial smooth muscle in allergic asthma
}

\author{
H Begueret, P Berger, J-M Vernejoux, L Dubuisson, R Marthan, J M Tunon-de-Lara
}

Thorax 2007;62:8-15. doi: 10.1136/thx.2006.062141

See end of article for authors' affiliations

.....................

Correspondence to: Dr J M Tunon-de-Lara, Laboratoire de Physiologie Cellulaire Respiratoire, INSERM E356 Université Bordeaux 2, 146 rue Léo Saignat, 33076 Bordeaux, France; manuel.

tunondelara@

u-bordeaux2.fr

Received 9 March 2006 Accepted 14 July 2006

\begin{abstract}
Background: Recent observations in asthma suggest that bronchial smooth muscle is infiltrated by inflammatory cells including mast cells. Such an infiltration may contribute to airway remodelling that is partly due to an increase in smooth muscle mass. Whether muscle increase is the result of smooth muscle cell hypertrophy remains controversial and has not been studied by ultrastructural analysis. A morphometric analysis of airway smooth muscle (ASM) was undertaken in asthmatic patients using electron microscopy to examine the interactions between ASM cells and inflammatory cells.

Methods: ASM specimens were obtained from 14 asthmatic subjects and nine non-asthmatic controls undergoing fibreoptic endoscopy. Inflammatory cell counts were assessed by immunohistochemistry, and ultrastructural parameters were measured using electron microscopy in a blinded fashion on smooth muscle cells and inflammatory cells.

Results: ASM from asthmatic patients was infiltrated by an increased number of mast cells and lymphocytes. Smooth muscle cells and their basal lamina were thicker in asthmatic patients $(9.5(0.8)$ and $1.4(0.2) \mu \mathrm{m})$ than in controls $(6.7(0.4)$ and $0.7(0.1) \mu \mathrm{m})$. In asthmatics the extracellular matrix was frequently organised in large amounts between ASM cells. Myofibroblasts within smooth muscle bundles were only observed in asthmatics, some of them displaying a close contact with ASM cells.

Conclusion: In asthma, airway myositis is characterised by a direct interaction between ASM cells and mast cells and lymphocytes. Smooth muscle remodelling was present, including cell hypertrophy and abnormal extracellular matrix deposition moulding ASM cells.
\end{abstract}

A sthma is an inflammatory disease characterised by bronchial hyperresponsiveness and infiltration of airway mucosa by several cell types including eosinophils and activated mast cell. Several studies have previously reported such an inflammatory response within the airway mucosa and fewer reports have provided ultrastructural data. ${ }^{1-7}$ Until recently, however, the study of inflammation was limited to the submucosa whereas the airway smooth muscle (ASM) was strictly considered as an effector that contracts and/or proliferates in response to inflammatory cell products.

It has recently been clearly demonstrated that mast cells also infiltrate the smooth muscle layer and that the number of mast cells infiltrating the smooth muscle is closely related to hyperresponsiveness. ${ }^{8}$ The mechanism of such mast cell infiltration involves the secretion of chemotactic factors by the ASM cells itself, including transforming growth factor $\beta_{1},{ }^{9}$ CXCL10 (IP10), ${ }^{10}$ and $\mathrm{CX}_{3} \mathrm{CLl}$ (fractalkine). ${ }^{11}$ Mast cells can produce a variety of lipid mediators, proteases, and cytokines that may interact with ASM cells, and in vitro studies have shown that mast cell products induce both bronchial hyperresponsiveness and ASM cell proliferation. ${ }^{12}{ }^{13}$ Other reports have suggested that T lymphocytes may also interact with ASM cells, and ligands involved in T cell activation have been detected at the surface of the ASM cells obtained from asthmatic tissues. $^{14}{ }^{15}$ Interactions between monocytes and ASM cells have also been studied in vitro and may influence tissue remodelling. ${ }^{16}$ Taken together, these findings suggest that, in asthma, the ASM is also infiltrated by a range of inflammatory cells that may directly interact with ASM cells and influence their function. However, a direct cell-cell interaction has not yet been confirmed within the ASM in asthma. Finally, because of difficulties in obtaining proper biopsy specimens, little is known about the ultrastructure of the ASM in asthma or the characteristics of inflammatory cell interactions with ASM cells.
Using electron transmission microscopy and morphometric analysis, we provide evidence for the first time that, in asthmatic patients, ASM cells display particular features of remodelling associated with direct interactions with mast cells, lymphocytes, and myofibroblasts.

\section{METHODS}

\section{Tissue specimens}

Sixteen subjects with asthma and 10 non-asthmatic controls were prospectively recruited to the study. All gave their written informed consent to participate and underwent fibreoptic bronchoscopy. The study received the approval from the local ethics committee (Comité Consultatif pour la Protection des Personnes en Recherche Biomédicale).

Asthma was defined according to ATS criteria and hyperresponsiveness was confirmed either by a significant reversibility $(>15 \%$ of baseline forced expiratory volume in 1 second $\left(\mathrm{FEV}_{\mathrm{l}}\right)$ ) or a positive methacholine challenge (concentration provoking a fall in $\mathrm{FEV}_{1}$ of $20 \%$ or more $\left.\left(\mathrm{PC}_{20}\right)<4 \mathrm{mg} / \mathrm{ml}\right)$. Asthmatic patients were non-smokers and atopy was defined according to EAACI. ${ }^{17}$

Control subjects were non-atopic, non-asthmatic patients with no respiratory history who were undergoing a fibreoptic fibroscopy because of haemoptysis or an abnormal image on the chest radiograph. They were asymptomatic, had no evidence of airway obstruction, and a $\mathrm{PC}_{20}$ for methacholine $>16 \mathrm{mg} / \mathrm{ml}$. Only subjects having a normal fibreoptic investigation and a normal bronchial mucosa were selected as controls. All control subjects were currently non-smokers or had stopped smoking for more than 3 years with a smoking history of less than 10 pack-years. The characteristics of the study subjects are shown in table 1 .

Abbreviations: $\mathrm{ASM}$, airway smooth muscle; $\mathrm{FEV}_{1}$, forced expiratory volume in 1 second 


\begin{tabular}{|c|c|c|c|}
\hline & $\begin{array}{l}\text { Asthmatics } \\
(n=14)\end{array}$ & $\begin{array}{l}\text { Controls } \\
(n=9)\end{array}$ & $p$ value \\
\hline \multicolumn{4}{|l|}{ Asthma severity } \\
\hline GINA 1 (n) & 2 & 0 & \\
\hline GINA 2 (n) & 2 & 0 & \\
\hline GINA 3 (n) & 2 & 0 & \\
\hline GINA 4 (n) & 8 & 0 & \\
\hline Asthma history (years) * & $25.8(4.2)$ & $0.0(0.0)$ & \\
\hline \multicolumn{4}{|l|}{ Current treatmentt } \\
\hline SABA (n) & 14 & 0 & \\
\hline ICS (n) & 10 & 0 & \\
\hline$\angle A B A(n)$ & 4 & 0 & \\
\hline Pred (n) & 2 & 0 & \\
\hline $\operatorname{Sex}(M / F)$ & $5 / 9$ & $6 / 3$ & \\
\hline Age (years) ${ }^{*}$ & $43.7(4.7)$ & $47.8(5.4)$ & 0.40 \\
\hline Atopy & Yes & No & \\
\hline $\mathrm{FEV}_{1}(\%)^{*}$ & $84.7(7.2)$ & $95.1(3.8)$ & 0.34 \\
\hline FVC $(\%)^{*}$ & $100.4(5.6)$ & $96.6(3.3)$ & 0.70 \\
\hline \multicolumn{4}{|c|}{$\begin{array}{l}\text { *Values are mean (SE). } \\
\text { †Treatments are short acting } \beta_{2} \text { agonist (SABA), inhaled corticosteroid (ICS), long acting } \beta_{2} \text { agonist (LABA), or oral } \\
\text { prednisolone } 20 \mathrm{mg} / \text { day (Pred). } \\
\text { GINA, Global Initiative for Asthma. FEV } \\
\text { p values from one way analyses of variance tests are indicated. }\end{array}$} \\
\hline
\end{tabular}

Assessable ASM was identified by a pathologist in a blinded fashion using both morphological characteristics and smooth muscle $\alpha$-actin staining. There was assessable ASM in the biopsy specimens from 14 asthmatics and nine controls. A mean of 10 serial sections per biopsy were examined for each subject.

\section{Immunohistochemistry}

Specimens were embedded in glycol methacrylate and processed as previously described. ${ }^{18}$ Primary antibodies included mouse anti-human c-kit (CD117, Dako), anti-tryptase (AAl, Dako), anti-CD3 (Dako), anti-CD68 (Dako), anti-neutrophil elastase (NE, Dako), EG2 antibody against the cleaved form of eosinophil cationic protein (Pharmacia), anti-Ki-67 (MIB-1, Dako), or the appropriate unrelated antibody. The number of positive cells was automatically assessed by Quancoul software (Bordeaux, France) at a magnification of $\times 200$, but only cells infiltrating the smooth muscle layer were taken into account by the pathologist. ${ }^{19}$ Cell counts were expressed as number of cells/ $\mathrm{mm}^{2}$ smooth muscle. The thickness of the subepithelial membrane was measured 10 times for each subject. Epithelial integrity, defined as the percentage of length of basement membrane with intact epithelium and the total area of smooth muscle layer were assessed ${ }^{20}{ }^{21}$ manually in a blinded fashion by a pathologist using Quancoul software at a magnification of $\times 200$. The smooth muscle area was normalised to the whole area of the corresponding biopsy and presented as a percentage of the whole area. The number of ASM cell nuclei was also assessed manually by a pathologist at a magnification of $\times 400$ and normalised by the surface of the ASM layer.

\section{Electron microscopy}

Biopsies were fixed in $2.5 \%$ glutaraldehyde in cacodylate buffer, post-fixed in $1 \%$ osmium tetroxide, dehydrated, and embedded in Epon. For each biopsy specimen, semi-thin sections $(1 \mu \mathrm{m}$ thick) were cut and stained with alkaline toluidine blue. The first semi-thin section large enough to span from the epithelium to the muscular layer was selected. Ten ultrathin serial sections ( $60 \mathrm{~nm}$ thick) were then cut on diamond knives. Three of these latter sections were subsequently randomly selected and placed on grids. Staining was performed with uracile acetate and lead citrate. Grids were then scanned by transmission electron microscopy (EM, Tecnai 12, Philips) and examined by a pathologist from left to right and from top to bottom to locate every whole nucleated ASM cell and inflammatory cell. Each ultrathin section was examined in its entirety.

We evaluated the mean width of both the nucleus and whole cell measured on sections at the nucleus level from 10 measurements per section. For these measurements, the within subject variability was assessed by the coefficient of error (a percentage of standard error of the mean divided by the mean). Each ASM cell is surrounded by an external lamina or basal membrane that is well identified using electron microscopy. We assessed both the mean thickness of the basal membrane from 10 measurements per section and the mean distance between two ASM cell basal membranes from 15 measurements per section.

Mast cells were located either in the submucosa or within the ASM layer-that is, muscular mast cells surrounded by ASM cells. Mast cells identified by electron microscopy were further subdivided into normal cells with intact electron dense granules or degranulated cells either by piecemeal or anaphylactic degranulation. Piecemeal degranulation was characterised by the presence of variable losses of dense contents from granules. ${ }^{42}$ Anaphylactic degranulation was characterised by extrusion of membrane-free granules into newly formed degranulation channels in the cytoplasm or through pores in the plasma membrane to the exterior environment. ${ }^{22}$ Both mechanisms of mast cell degranulation involved one to all granules (partially to totally degranulated mast cells). As previously described, the variable ultrastructural patterns of mast cell granules were classified as cored (homogeneously dense granules almost impenetrably black), scrolled (scrolled matrix free of particulate material), particulated (granule content varying from finely particulate to stippled or ropey), or mixed (mixtures of these patterns). ${ }^{42}$ Myofibroblasts were identified according to morphological criteria described by Eyden. ${ }^{23}$ Specific ultrastructural characteristics are the presence of fibronexus defined as the cell surface point of convergence of intracellular myofilaments and extracellular fibronectin filaments, cell surface component referred to as basement membrane-like material, and poorly developed smooth muscle myofilaments.

Computerised photographs and measurements were performed in a blinded fashion using the Analysis Soft Imaging 


\begin{tabular}{|c|c|c|c|}
\hline & $\begin{array}{l}\text { Asthmatics } \\
(n=14)\end{array}$ & $\begin{array}{l}\text { Controls } \\
(n=9)\end{array}$ & $\mathrm{p}$ values \\
\hline CD117 & $16.3(2.5-51.0)$ & $4.4(0.0-10.8)$ & 0.04 \\
\hline $\mathrm{AAl}$ & $19.6(0.0-37.6)$ & $4.4(0.0-10.8)$ & 0.04 \\
\hline EG2 & $0.0(0.0-0.0)$ & $0.0(0.0-0.0)$ & 0.57 \\
\hline $\mathrm{CD} 3$ & $9.2(4.7-15.3)$ & $0.0(0.0-6.0)$ & 0.02 \\
\hline CD68 & $3.9(0.0-10.1)$ & $0.0(0.0-3.8)$ & 0.17 \\
\hline NE & $0.0(0.0-0.0)$ & $0.0(0.0-0.0)$ & 0.90 \\
\hline
\end{tabular}

System and mast cell granules were counted visually at a standard magnification of $\times 16500$.

\section{Statistical analysis}

Subject characteristics, epithelial integrity, ASM cell nuclei concentration, and smooth muscle area, expressed as mean (SE), were normally distributed and compared with one way analyses of variance (ANOVA) tests. Subepithelial membrane thicknesses were measured 10 times for each subject and were compared with repeated measures ANOVA. Cell counts, expressed as median (interquartile range), were not normally distributed and were thus compared using the one way analyses of variance Kruskal-Wallis tests. Correlations between $\mathrm{FEV}_{1}$ and inflammatory cell counts were performed using Spearman correlation rank tests. Data on ultrastructural characteristics are reported as mean (SE) values and were compared using one way analyses of variance ANOVA or unpaired $t$ tests. The presence/absence of myofibroblasts between ASM cells in asthmatic and non-asthmatic bronchi were compared using Fisher's exact test. All analyses were performed with NCSS software (NCSS Statistical software, Kaysville, UH, USA).

\section{RESULTS}

\section{Airway remodelling}

Specimens from asthmatic patients were characterised by epithelial damage and a thickened subepithelial membrane compared with control specimens. The epithelial integrity was lower in asthmatics than in control subjects (48.9 (3.5)\% $v 72.2$ $(2.3) \%, \mathrm{p}<0.0001)$, and the subepithelial membrane was thicker in asthmatics than in controls $(8.2(0.6 \mu \mathrm{m} v 4.7$ (0.8) $\mu \mathrm{m}, \mathrm{p}<0.0001)$.

Specimens from asthmatic patients were also characterised by a thickened ASM. The normalised smooth muscle areas for asthmatic and control subjects were 39.9 (3.6)\% and 20.8 (3.8)\% of total area, respectively $(p=0.002)$. The number of ASM cell nuclei $/ \mathrm{mm}^{2}$ was not significantly different between asthmatics and controls (1081 (129) v 926 (76), p=0.38). Whereas Ki67 positive cells were found within the epithelial layer, no Ki67 positive cells were found in the smooth muscle layer from asthmatic patients or control subjects. No aspect of mitoses was found in the smooth muscle layer. Eosinophilic infiltration of the submucosa was seen in asthmatic specimens compared with controls (median (IQR) 19.4 (14.4-45.1) $v 0.0$ $(0.0-1.2)$ cells $\left./ \mathrm{mm}^{2}, \mathrm{p}<0.0001\right)$.

\section{Infiltration of ASM by inflammatory cells}

Immunohistochemical analysis revealed the presence of more mast cells and lymphocytes within the ASM layer from asthmatic patients than from control subjects (table 2). Only cells surrounded by ASM cells were considered as muscular inflammatory cells (fig 1).
There was no significant correlation between asthma severity according to $\mathrm{FEV}_{1}$ and smooth muscle infiltration by any inflammatory cell types (data not shown). In two samples from asthmatic patients we detected the presence of eosinophils in the smooth muscle layer associated with a very high concentration of eosinophils in both the epithelium and submucosa.

\section{Ultrastructural analysis of ASM cells}

An ultrastructural analysis of the smooth muscle was performed in Epon embedded samples from nine asthmatic subjects and five controls. ASM cells were characterised by a spindle shape, an elongated nucleus with a blunt end, and the presence of dense bodies within the cytoplasm corresponding to the organisation of smooth muscle myofilaments (fig 2). The morphometric parameters of ASM cells from asthmatics and controls are shown in table 3. The mean ASM cell size was larger in asthmatic patients than in control subjects whereas the within subject variability was similar $(2.1 \%$ and $2.3 \%$, respectively). We also observed significant variations in ASM

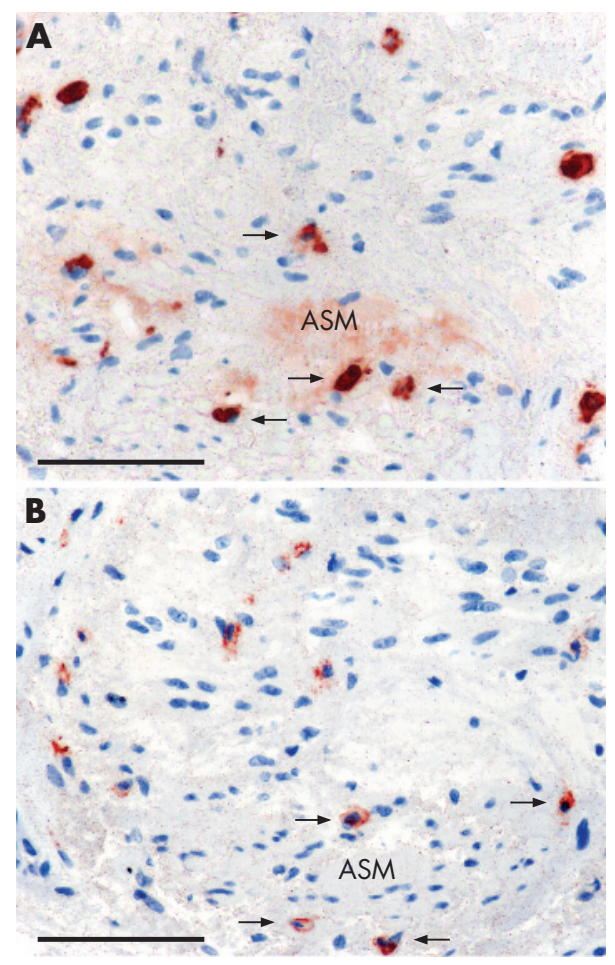

Figure 1 Infiltration of asthmatic airway smooth muscle (ASM) by inflammatory cells. (A) Mast cells are stained with antitryptase antibody. (B) Lymphocytes are stained with anti-CD3 antibody. Arrows indicate cells within the ASM layer. Sections are counterstained with Mayer's haematoxylin. Bars represent $50 \mu \mathrm{m}$. 

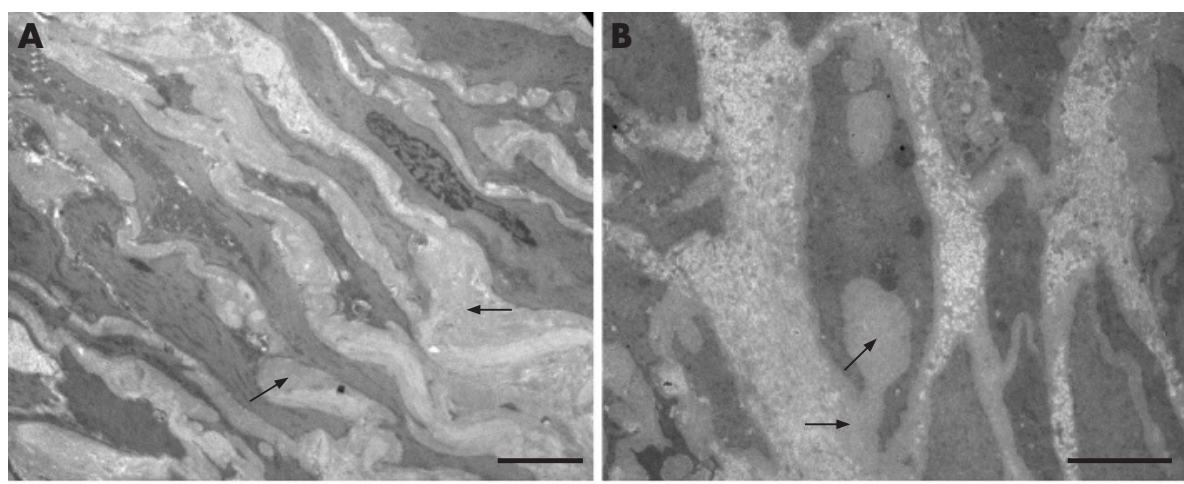

Figure 2 Ultrastructural characteristics of airway smooth muscle (ASM) cells and extracellular matrix deposition. Longitudinal sections show a thicker extracellular matrix deposition (arrows) surrounding ASM cells in (A) an asthmatic patient than in a control subject (C). In transverse sections the extracellular matrix is frequently organised into large bland amounts of matrix protein deposits (arrows) moulding ASM cells in asthmatic patients (B); this feature was not observed in control subjects (D). Bars represent $10 \mu \mathrm{m}$.
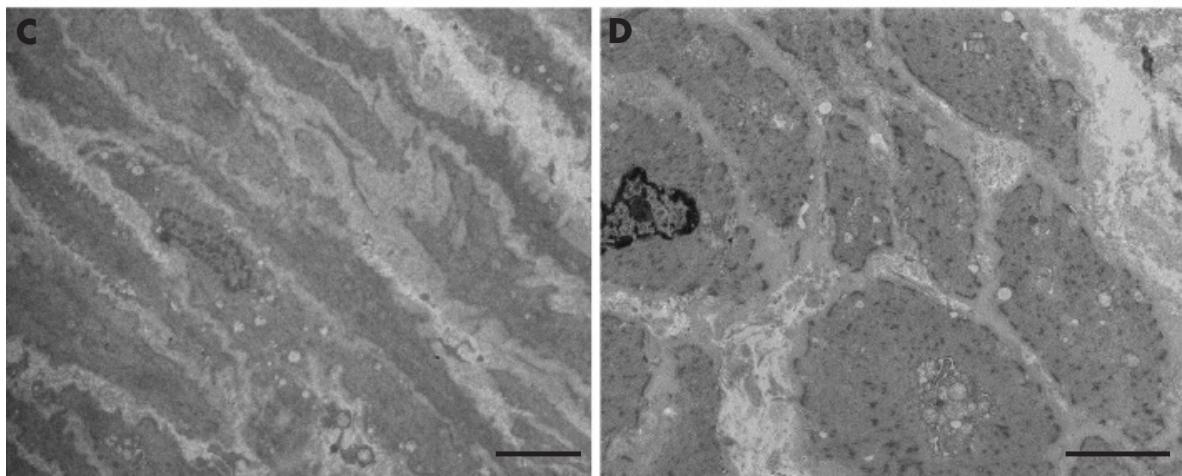

cell basement membrane thickness and in extracellular matrix deposition. When comparing both groups, mean ASM cell basal lamina thickness was larger in asthmatic patients. The extracellular matrix was frequently organised into large numbers of moulding ASM cells and displayed non-fibrillar ultrastructural features (fig 2A, B). These features were not observed in specimens obtained from non-asthmatic controls (fig 2C, D).

\section{Ultrastructural analysis of cells infiltrating the smooth muscle layer}

As mentioned above, we analysed various cell types infiltrating the smooth muscle layer and only considered cells totally surrounded by ASM cells.
Mast cells

In asthmatic specimens the muscular mast cells were smaller than the submucosal mast cells (143.9 (5.3) $v 259.9(22.1) \mu \mathrm{m}^{2}$, $\mathrm{p}=0.01)$ whereas their nuclear area was not significantly different (38.7 (2.1) v $\left.67.2(9.6) \mu \mathrm{m}^{2}, \mathrm{p}=0.09\right)$. Muscular mast cells had very few short cytoplasmic processes or pseudopods compared with submucosal mast cells. Nevertheless, they had close contacts with ASM cells (fig 3A) which was also observed in control specimens (fig 3B). Muscular mast cells displayed a pattern of degranulation with a mean number of granules lower than that of submucosal mast cells (19.1 (1.6) $v 55.2$ (8.1) $\mu \mathrm{m}^{2}, \mathrm{p}=0.02$ ). Nevertheless, the mean area of these granules was similar in both muscular and submucosal mast

Table 3 Morphological parameters of ASM cells from asthmatic and control subjects

\begin{tabular}{|c|c|c|c|c|c|}
\hline & $\begin{array}{l}\text { Whole cell mean } \\
\text { size }(\mu \mathrm{m})\end{array}$ & $\begin{array}{l}\text { Nuclei mean size } \\
(\mu \mathrm{m})\end{array}$ & $\begin{array}{l}\text { Distance between } \\
\text { ASM cell BM }(\mu \mathrm{m})\end{array}$ & $\begin{array}{l}\text { ASM cell BM } \\
\text { thickness }(\mu \mathrm{m})\end{array}$ & $\begin{array}{l}\text { Presence of myofibroblasts } \\
\text { between ASM cells }\end{array}$ \\
\hline \multicolumn{6}{|l|}{ Asthmatics } \\
\hline 1 & 9.92 & 4.43 & 1.33 & 1.61 & No \\
\hline 2 & 8.20 & 6.26 & 0.81 & 0.75 & Yes \\
\hline 3 & 11.06 & 3.01 & 1.57 & 2.62 & Yes \\
\hline 4 & 7.29 & 3.12 & 0.52 & 1.00 & Yes \\
\hline 5 & 7.83 & 4.71 & 1.14 & 0.62 & Yes \\
\hline 6 & 6.33 & 7.01 & 1.39 & 1.70 & No \\
\hline 7 & 14.31 & 9.53 & 1.95 & 1.28 & Yes \\
\hline 8 & 9.75 & 2.19 & 0.84 & 0.94 & Yes \\
\hline 9 & 10.88 & 3.68 & 1.21 & 1.82 & Yes \\
\hline Mean (SE) & $9.5(0.8)$ & $4.9(0.8)$ & $1.2(0.1)$ & $1.4(0.2)$ & \\
\hline \multicolumn{6}{|l|}{ Controls } \\
\hline 1 & 5.60 & 3.01 & 1.60 & 0.60 & No \\
\hline 2 & 6.30 & 3.52 & 1.56 & 0.61 & No \\
\hline 3 & 7.51 & 4.61 & 1.28 & 0.66 & No \\
\hline 4 & 7.76 & 5.01 & 1.71 & 1.01 & No \\
\hline 5 & 6.12 & 3.81 & 1.34 & 0.63 & No \\
\hline Mean (SE) & $6.7(0.4)$ & $4.0(0.4)$ & $1.5(0.1)$ & $0.7(0.1)$ & \\
\hline$p$ values & 0.03 & 0.43 & 0.17 & 0.04 & 0.02 \\
\hline
\end{tabular}

$p$ values from one way analyses of variance or Fisher's exact tests are indicated. ASM, airway smooth muscle; BM, basal membrane. 

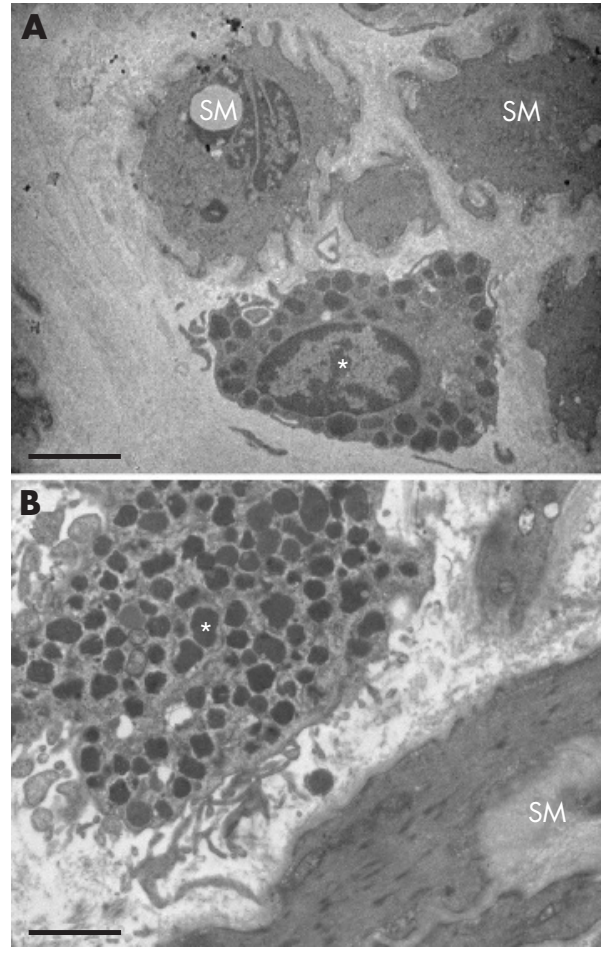

Figure 3 Ultrastructural characteristics of mast cells in the airway smooth muscle (SM) layer of (A) asthmatic subjects and (B) controls. The mast cells (*) are small and display few cytoplasmic pseudopods and granules in asthmatic patients. In controls the mast cells (*) are larger, display more cytoplasmic pseudopods, and contain more electron dense granules. Bars represent $5 \mu \mathrm{m}$.

cells $\left(1.5(0.3) \quad v 2.0(0.1) \mu \mathrm{m}^{2}, \mathrm{p}=0.11\right)$, although their ultrastructural appearance was different. From a total of 523 granules, the mean (SE) percentage of cored granules was 75.3
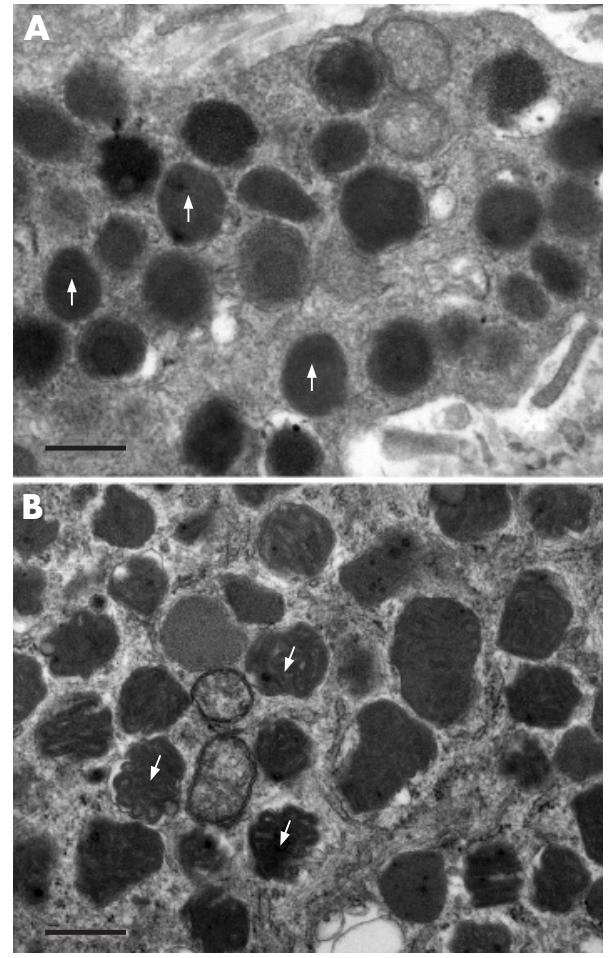

Figure 5 Ultrastructure of secretory granules of mast cells in the airway smooth muscle layer of (A) asthmatics and (B) controls. Granules are predominantly dense cored (arrows) in asthmatics and scrolled (arrows) in control subjects. Bars represent $1 \mu \mathrm{m}$.

(13.2)\% in the smooth muscle layer and only $17.6(5.2) \%$ in the submucosa $(p=0.001)$. The percentages of scrolled, particulated, or mixed granules were not significantly different between the two sites.
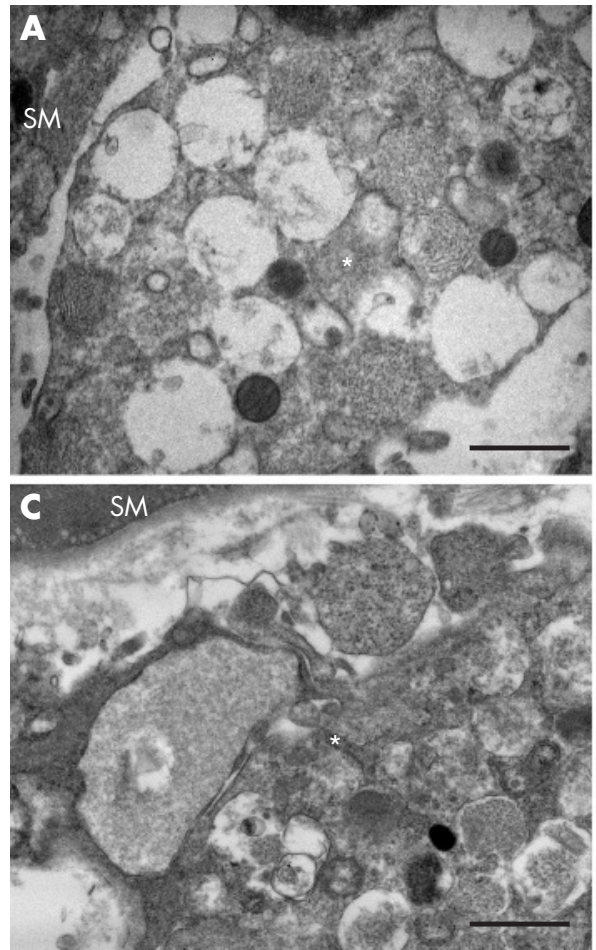
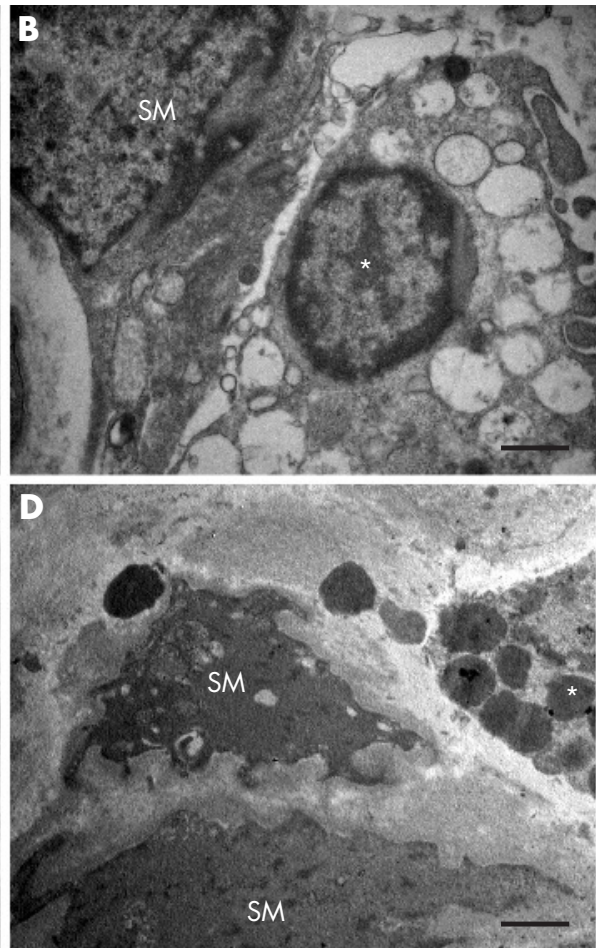

Figure 4 Ultrastructural features of mast cell $\left({ }^{*}\right)$ degranulation in the airway smooth muscle (SM) layer observed in a

representative specimen from an asthmatic patient. (A) Piecemeal degranulation with completely or partially empty non-fused granules. (B) Whole degranulation with totally empty non-fused granules. (C) Anaphylactic degranulation with granule fusion, alteration of granule content, and degranulation channel formation. (D) Exocytosis of altered membrane-free granules. Bars represent $2 \mu \mathrm{m}$. 

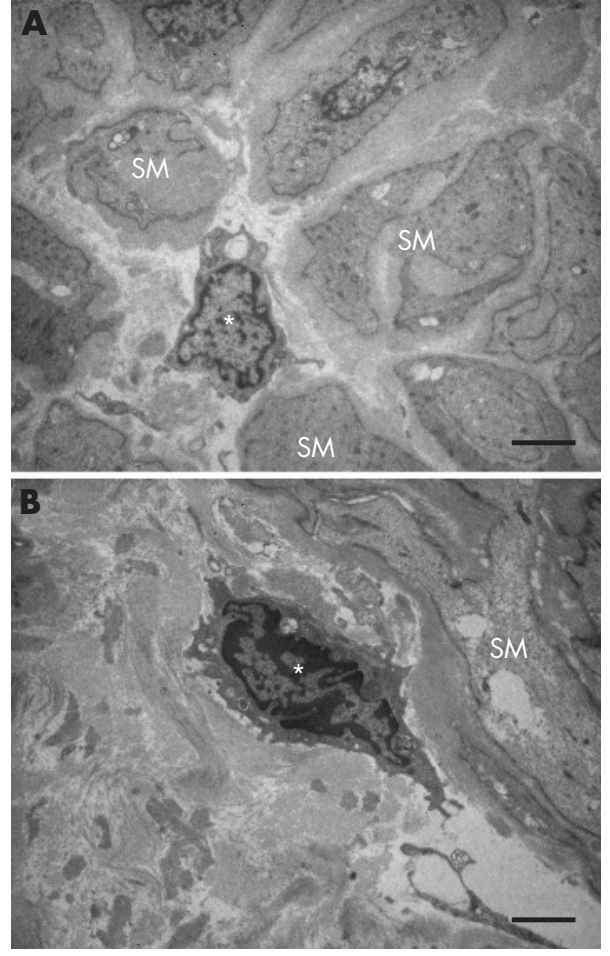

Figure 6 Ultrastructural appearance of interactions between lymphocytes and airway smooth muscle (SM) cells from an asthmatic patient. (A) A lymphocyte (*) with a regular nucleus does not interact directly with the SM cell. (B) An activated lymphocyte (*) with a large cleaved nucleus interacts with the thick extracellular matrix surrounding the airway SM cell. Bars represent $5 \mu \mathrm{m}$.

When the asthmatic subjects and controls were compared, muscular mast cells in asthmatic patients had fewer cytoplasmic pseudopods and were smaller than those of control subjects (143.9 (5.3) $\left.v 386.7(68.4) \mu \mathrm{m}^{2}, \mathrm{p}=0.03\right)$. Furthermore, most of the muscular mast cells from the asthmatic group were partially or totally degranulated; this was not seen in the control group. Degranulation corresponded to the loss of dense content from granules (fig 4A, B). Again, the mean number of granules was lower in the smooth muscle layer in asthmatic subjects than in controls (19.1 (1.6) v $99.0 \quad(26.0) \mu \mathrm{m}^{2}$, $\mathrm{p}=0.03$ ). These losses were either focal within single granules, complete losses of single granule contents, or partial to complete losses of dense material from variable numbers of cytoplasmic granules. The end result of such granule loss was the presence of non-fused, empty, electron lucent granule containers in undamaged mast cells. Some of these containers were larger than the granules. Morphological evidence for "anaphylactic" degranulation was infrequent and was observed in one case in the ASM (fig 4C) and in two cases in the submucosa. Features of mast cell degranulation by exocytosis or discharge of the granule contents were observed in the interstitial matrix and in the ASM (fig 4D). Some of these mast cell granules in the ASM layer were very close to ASM cells. Again, none of these features was observed in control subjects. The percentage of cored secretory granules in muscular mast cells from asthmatics was higher than that of controls $(75.3$ $(13.2) \%$ from 57 granules $v 9.0$ (4.0)\% from 198 granules, $p=0.03$; fig $5 \mathrm{~A}$ ), whereas the percentage of scrolled granules in muscular mast cells from asthmatics was lower than that of controls $(12.0(7.1) \% \quad v 86.5 \quad(4.5) \%, p=0.01$; fig 5B). The extruded granules were always altered dense cored membranefree granules.
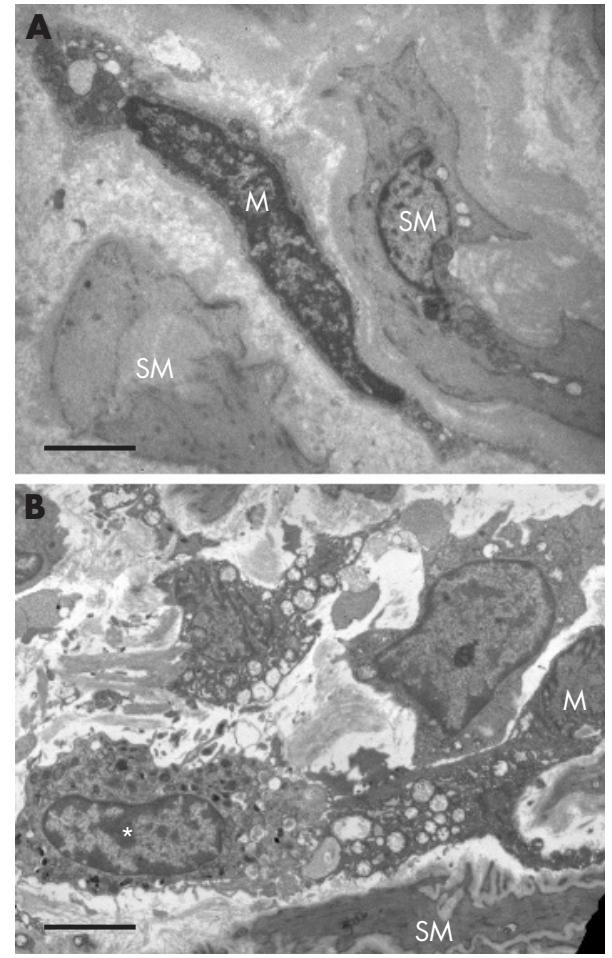

Figure 7 Myofibroblast within airway smooth muscle layer from asthmatic patient. (A) A spindle myofibroblast $(M)$ is located between two airway smooth muscle (SM) cells. (B) A myofibroblast (M) directly interacts with a degranulating mast cell $\left({ }^{*}\right)$ with close cell-cell contact. Bars represent $5 \mu \mathrm{m}$.

\section{Other cells}

Inflammatory cell infiltration in the bronchial muscular layer also included lymphocytes, monocytes/macrophages, and rare neutrophils as observed using immunohistochemistry. Close contacts were observed between lymphocytes and ASM cells (fig 6). By contrast, no eosinophils were detected in the ASM using electron microscopy in asthmatic or control subjects. Some basophils were identified in the submucosa of two asthmatic patients but not within the smooth muscle layer.

Besides mast cells, myofibroblasts were the cells most commonly observed within the ASM, occurring in seven out of nine asthmatic patients between ASM cell bundles (fig 7A). They were defined by spindle cells displaying prominent rough endoplasmic reticulum, a cell surface component referred to as basement membrane-like material sometimes with fibronexus features, and poorly developed smooth muscle myofilaments. Some of these myofibroblasts had close contact with mast cells and ASM cells (fig 7B). The presence of fibroblasts within the ASM layer was observed in both asthmatic and control groups with no ultrastructural differences.

\section{DISCUSSION}

Chronic inflammation is recognised as an important aspect of the pathogenesis of asthma, leading to architectural remodelling. In the airways it is suggested that this remodelling (collagen deposition and/or altered distribution, mucous gland hypertrophy, neovascularisation, smooth muscle hyperplasia/ hypertrophy) contributes to long term irreversible changes, fixed obstruction, and severity of the asthmatic disease.

In the present study ASM remodelling ${ }^{24}$ was found in all asthmatic specimens and could not be observed in specimens from controls. Our control subjects were asymptomatic, nonasthmatic and non-atopic, with no respiratory history. All of the 
asthmatic patients were atopic and therefore our results may not be generalisable to all asthmatics. It concerned both ASM and related cells. ASM cells in asthmatics were larger, which agrees with the findings of previous studies reporting ASM cell hypertrophy in asthma, ${ }^{21}{ }^{25}$ although a recent study failed to confirm this observation. ${ }^{26}$ In our specimens no ultrastructural features of ASM cell mitoses were observed, suggesting the absence of proliferation activity. This finding was strengthened by the absence of Ki67 staining within the smooth muscle layer, although a study specifically aimed at examining hyperplasia was not performed. These results are not directly comparable to those recently published by Woodruff and colleagues who reported hyperplasia of ASM cells and a lack of hypertrophy in mild and moderate asthma. ${ }^{26}$ While we measured the actual surface of the cells using electron microscopy, Woodruff and coworkers calculated the volume of cells from the number of cells analysed by optical microscopy. ${ }^{26}$ With regard to the extracellular matrix, we observed a thicker ASM cell basement membrane and large amounts of bland matrix protein deposits close to ASM cells with features of moulding. Such intercellular protein deposition was a consistent ultrastructural feature that has never previously been reported in asthmatic airways. These ultrastructural data thus show that the increase in bronchial muscle mass in asthma is multifactorial and includes ASM cell hypertrophy, basal lamina thickening, increased extracellular matrix deposits, and collagen deposition within and around ASM bundles.

In these experiments, immunohistochemistry and electron microscopy confirmed the previous finding of mast cell myositis in asthma. ${ }^{27}$ Previous observations of large amounts of mast cells infiltrating the ASM have been particularly in cases of severe asthma. ${ }^{28}$ However, the relationship between mast cell myositis and asthma severity is not clear. In our study there was no correlation between asthma severity and mast cell infiltration of the smooth muscle layer. It should also be noted that mast cell infiltration of the ASM is correlated with airway obstruction in other diseases such as COPD..$^{29} 30$

Besides a quantitative approach based on immunohistochemistry, it is important to document qualitative aspects using electron microscopy. As already reported, electron microscopy and morphometric analysis provide evidence for human bronchial mast cell heterogeneity. In the mucosa, mast cell degranulation increasing from the lumen towards the peripheral tissue has been reported. ${ }^{4}$ This gradient probably accounts for the apparent heterogeneity in bronchial mast cells. In our study mast cell degranulation in asthmatic tissue also increased from the lower level in the submucosa to the muscular layer. The total number of mast cell granules was lower in the ASM and the ultrastructural appearance of the granules was different. There was also a significant reduction in mean mast cell area from the submucosa to the muscular layer. Morphologically, muscular mast cells have shorter cytoplasmic processes or pseudopods than submucosal mast cells. This may suggest that submucosal mast cells are in transit, migrating either towards the subepithelium or towards the muscular layer, as these two locations are effective sites of mast cell adhesion and/or activation. Two patterns of degranulation were observed-one defined by partially or largely empty secretory cytoplasmic granules and the other by secretory granule exocytosis in the extracellular matrix. This latter pattern was observed in the submucosa and in the muscular layer, along with the presence of free altered granules in the connective tissue. In some cases, free secretory granules were observed very close to ASM cells, further confirming that the muscular layer is an effective site of mast cell degranulation. In addition, the ultrastructural appearance of mast cell granules shows that most mast cells infiltrating the smooth muscle layer contain cored granules.

Using both optical and electron microscopy, we found that, besides mast cells, other inflammatory cells were located within the smooth muscle layer. Lymphocytes and macrophages were the most frequently observed cells, but only the number of lymphocytes was significantly higher in asthmatic patients. This observation has not been made previously, although lymphocyte infiltration has already been reported in some asthmatic patients. ${ }^{8}$ Immunohistochemistry and morphological analyses indicate that these lymphocytes are T cells, sometimes irregularly shaped, and displaying a close contact with both ASM cells and myofibroblasts. These results are in agreement with the recent finding that smooth muscle cells from both normal and asthmatic subjects express the OX40 ligand, a member of the TNF receptor family, and interact with $\mathrm{T}$ cells that express OX40 following the activation of the $\mathrm{T}$ cell receptor. ${ }^{15}$ Activation of OX40 by OX40L would thus result in production of interleukin 6 by ASM cells and facilitate the Th2 response. In addition, such an interaction would strengthen the recent hypothesis that activated $\mathrm{CD} 4+\mathrm{T}$ cells drive ASM remodelling through a direct cell-cell interaction. ${ }^{24}$

Myofibroblasts were also detected between ASM bundles from seven out of nine asthmatic patients. This cell type remains particularly difficult to define since it expresses features from both smooth muscle cells and fibroblasts. Circulating fibrocytes have been shown to differentiate into bronchial myofibroblasts after allergen exposure in asthmatic mice. ${ }^{31}$ In addition, tryptase stimulated human fibroblasts express smooth muscle $\alpha$-actin and thus become myofibroblasts that are able to contract a collagen matrix in vitro. ${ }^{32}$ This finding is consistent with the close relationship observed in the present study between mast cells and myofibroblasts (fig 7B). Moreover, such an interaction is in agreement with the very recent observation that myofibroblasts from asthmatic subjects produce smooth muscle related transcripts after stimulation by transforming growth factor $\beta .^{33}$ Myofibroblasts are not correctly detected by conventional morphological or immunohistochemical techniques since they do not express specific markers. They are positive for both smooth muscle actin and vimentin antigens like ASM cells. In this study we used previously published ultrastructural criteria to precisely define myofibroblasts as spindle cells with prominent rough endoplasmic reticulum, fibronexus, and basement membrane-like material. ${ }^{23}$ Their presence, restricted to asthmatic patients, could contribute to ASM cell hyperplasia. However, further studies are needed to show that these myofibroblasts can effectively differentiate into actual ASM cells. Myofibroblasts could therefore be viewed as a precursor of smooth muscle cells, ${ }^{23}$ but also as the result of a dedifferentiation process of the smooth muscle.

Taken together, these results indicate that, in atopic asthmatic patients, the ASM is infiltrated by several inflammatory cells among which mast cells and lymphocytes may play a specific role. Electron microscopy has revealed close contact between the products of mast cell degranulation and the smooth muscle cells, in agreement with previous in vitro studies of the effect of stored mediators on smooth muscle function. Other cells detected in the ASM are lymphocytes and myofibroblasts; these may have an important role in the initial response to allergen and in the remodelling process, respectively.

\section{ACKNOWLEDGEMENTS}

The authors thank the Department of Pathology of Hôpital Pellegrin (CHU de Bordeaux) for the ultrastructural technical assistance. 


\section{Authors' affiliations}

H Begueret, P Berger, R Marthan, J M Tunon-de-Lara, Université Bordeaux 2, Laboratoire de Physiologie Cellulaire Respiratoire, F-33076, Bordeaux; Inserm E356 F-23076, Bordeaux, France

J M Vernejoux, J M Tunon-de-Lara, CHU de Bordeaux, Service des Maladies Respiratoires, F-33076, Bordeaux, France

L Dubuisson, Université Bordeaux 2, Service de Microscopie Electronique, F-33076, Bordeaux, France

This study was supported by a grant PHRC (Programme Hospitalier de Recherche Clinique) 2002 from the CHU de Bordeaux and a grant from FRM (Fondation Recherche Médicale) DAL2005120574.

Competing interests: none declared.

\section{REFERENCES}

1 Lamb D, Lumsden A. Intra-epithelial mast cells in human airway epithelium evidence for smoking-induced changes in their frequency. Thorax 1982;37:334-42

2 Franconi GM, Rubinstein I, Levine EH, et al. Mechanical removal of airway epithelium disrupts mast cells and releases granules. Am J Physiol 1990;259:L372-7.

3 Diukanovic R, Wilson JW, Britten KM, et al. Quantitation of mast cells and eosinophils in the bronchial mucosa of symptomatic atopic asthmatics and healthy control subjects using immunohistochemistry. Am Rev Respir Dis 1990; 142:863-71.

4 Heard BE, Dewar A, Nunn AJ, et al. Heterogeneous ultrastructure of human bronchial mast cells: morphometric subdivision of cell types and evidence for a degranulation gradient. Am J Respir Cell Mol Biol 1990;3:71-8.

5 Ohashi Y, Motojima S, Fukuda T, et al. Airway hyperresponsiveness, increased intracellular spaces of bronchial epithelium, and increased infiltration of eosinophils and lymphocytes in bronchial mucosa in asthma. Am Rev Respir Dis 1992;145: 1469-76.

6 Gizycki MJ, Adelroth E, Rogers AV, et al. Myofibroblast involvement in the allergen-induced late response in mild atopic asthma. Am J Respir Cell Mol Biol 1997: 16:664-73

7 Cokugras H, Akcakaya N, Seckin, et al. Ultrastructural examination of bronchial biopsy specimens from children with moderate asthma. Thorax 2001;56:25-9.

8 Brightling CE, Bradding P, Symon FA, et al. Mast-cell infiltration of airway smooth muscle in asthma. N Engl J Med 2002;346:1699-705.

9 Berger P, Girodet PO, Begueret H, et al. Tryptase-stimulated human airway smooth muscle cells induce cytokine synthesis and mast cell chemotaxis. Faseb J 2003;17:2139-41.

10 Brightling CE, Ammit AJ, Kaur D, et al. The CXCL10/CXCR3 axis mediates human lung mast cell migration to asthmatic airway smooth muscle. Am J Respir Crit Care Med 2005; 171:1 103-8.

11 El-Shazly A, Berger P, Girodet PO, et al. Fraktalkine produced by airway smooth muscle cells contributes to mast cell recruitment in asthma. J Immunol 2006;176:1860-8.

12 Berger P, Compton SJ, Molimard M, et al. Mast cell tryptase as a mediator of hyperresponsiveness in human isolated bronchi. Clin Exp Allergy 1999;29:804-12.
13 Berger P, Perng DW, Thabrew $\mathrm{H}$, et al. Tryptase and agonists of PAR-2 induce the proliferation of human airway smooth muscle cells. J Appl Physiol 2001;91:1372-9.

14 Lazaar AL, Albelda SM, Pilewski JM, et al. T lymphocytes adhere to airway smooth muscle cells via integrins and CD44 and induce smooth muscle cell DNA synthesis. J Exp Med 1994;180:807-16.

15 Burgess JK, Blake AE, Boustany S, et al. CD40 and OX40 ligand are increased on stimulated asthmatic airway smooth muscle. J Allergy Clin Immunol 2005; 115:302-8.

16 Zhu YK, Liu X, Wang $\mathrm{H}$, et al. Interactions between monocytes and smoothmuscle cells can lead to extracellular matrix degradation. J Allergy Clin Immunol $2001 ; 108: 989-96$

17 Johansson SG, Hourihane JO, Bousquet J, et al. A revised nomenclature for allergy. An EAACl position statement from the EAACl nomenclature task force. Allergy 2001:56:813-24.

18 Berger P, Walls AF, Marthan R, et al. Immunoglobulin E-induced passive sensitization of human airways: an immunohistochemical study. Am J Respir Crit Care Med 1998;157:610-6.

19 Berger P, Lavallee J, Rouiller R, et al. Assessment of bronchial inflammation using an automated cell recognition system based on colour analysis. Eur Respir J 1999; 14:1394-402.

20 Amin K, Ludviksdottir D, Janson C, et al. Inflammation and structural changes in the airways of patients with atopic and nonatopic asthma. Am J Respir Crit Care Med 2000:162:2295-301.

21 Benayoun L, Druilhe A, Dombret MC, et al. Airway structural alterations selectively associated with severe asthma. Am J Respir Crit Care Med 2003;167:1360-8.

22 Dvorak AM. Ultrastructural analysis of human mast cells and basophils. Chem Immunol 1995:61:1-33.

23 Eyden B. The myofibroblast: an assessment of controversial issues and a definition useful in diagnosis and research. Ultrastruct Pathol 2001;25:39-50.

24 Ramos-Barbon D, Presley JF, Hamid QA, et al. Antigen-specific CD4+ T cells drive airway smooth muscle remodeling in experimental asthma. J Clin Invest 2005; 115:1580-9.

25 Ebina M, Takahashi T, Chiba T, et al. Cellular hypertrophy and hyperplasia of airway smooth muscles underlying bronchial asthma. A 3-D morphometric study. Am Rev Respir Dis 1993;148:720-6.

26 Woodruff PG, Dolganov GM, Ferrando RE, et al. Hyperplasia of smooth muscle in mild to moderate asthma without changes in cell size or gene expression. Am J Respir Crit Care Med 2004; 169:1001-6.

27 Berger P, Girodet PO, Tunon De Lara JM. Mast cell myositis: a new feature of allergic asthma? Allergy 2005;60:1238-40.

28 Carroll NG, Mutavdzic S, James AL. Distribution and degranulation of airway mast cells in normal and asthmatic subjects. Eur Respir J 2002;19:879-85.

29 Tunon-de-Lara JM, Berger P, Begueret $\mathrm{H}$. Mast cells in airway smooth muscle. N Engl J Med 2002;347:1040-1.

30 Berger $\mathbf{P}$, Laurent $\mathrm{F}$, Begueret $\mathrm{H}$, et al. Structure-function of small airways in smokers: relationship between air trapping on CT and airway inflammation. Radiology 2003;228:85-94

31 Schmidt $M$, Sun $G$, Stacey $M A$, et al. Identification of circulating fibrocytes as precursors of bronchial myofibroblasts in asthma. J Immunol 2003;171:380-9.

32 Skold CM, Ohkuni Y, Liu XD, et al. Co-cultured human mast cells stimulate fibroblast-mediated contraction of collagen gels. Inflammation 2001;25:47-51

33 Wicks J, Haitchi HM, Holgate ST, et al. Enhanced upregulation of smooth musclerelated transcripts by TGF $\beta$ in asthmatic (myo)fibroblasts. Thorax $2006 \cdot 61 \cdot 313-9$

\section{bmjupdates+}

bmjupdates+ is a unique and free alerting service, designed to keep you up to date with the medical literature that is truly important to your practice.

bmjupdates+ will alert you to important new research and will provide you with the best new evidence concerning important advances in health care, tailored to your medical interests and time demands.

Where does the information come from?

bmjupdates+ applies an expert critical appraisal filter to over 100 top medical journals A panel of over 2000 physicians find the few 'must read' studies for each area of clinical interest

Sign up to receive your tailored email alerts, searching access and more...

www.bmjupdates.com 